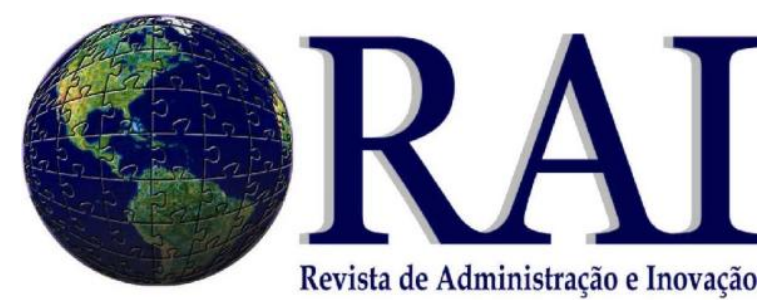

\title{
ARTICLES \\ TECHNOLOGY TRANSFER WITHIN MNES: INTER-SUBSIDIARY COMPETITION AND COOPERATION
}

\section{Dan Li}

PhD Business Administration pela Universidade do Texas Professora da Kelley School of Business Indiana University

E-mail: lid@indiana.edu [EUA]

\section{Manuel Portugal Ferreira}

PhD Business Administration pela David Eccles School of Business da Universidade e Utah Professor da Escola Superior de Tecnologia e Gestão Instituto Politécnico de Leiria E-mail: portugal@estg.ipleiria.pt [Portugal]

\section{Fernando Ribeiro Serra}

Doutor em Engenharia pela Pontifícia Universidade Católica do Rio de Janeiro - PUC Professor do Programa do Mestrado em Administração da Universidade do Sul de Santa Catarina - UNISUL E-mail: fernando.serra@unisul.br [Brasil]

\begin{abstract}
Much theory and research that seeks to explain why and how technology transfers occur within multinational enterprises (MNEs) actually addresses the question of how these transfers occur among cooperative subsidiaries, and relies on the assumption of inter-subsidiary cooperation. However, subsidiaries do not always cooperate. We suggest that the success of technology transfer among subsidiaries depends on the extent to which the relationships among an MNE's subsidiaries (i.e. intersubsidiary) are competitive or cooperative. Inter-subsidiary cooperation is determined by the MNE's international strategy, organizational structure, and the social relationships among subsidiaries. Both hierarchical and social relational factors drive the potential for inter-subsidiary multimarket competition that originates from the overlap on the subsidiaries' products, technologies, and market portfolios.
\end{abstract}

Keywords: Technology transfer, subsidiaries, competition and cooperation, international strategy.

RAI - Revista de Administração e Inovação ISSN: 1809-2039

Organização: Comitê Científico Interinstitucional

Editor Científico: Milton de Abreu Campanario

Avaliação: Double Blind Review pelo SEER/OJS

Revisão: gramatical, normativa e de formatação

RAI - Revista de Administração e Inovação, São Paulo, v. 6, n. 1, p. 139-158, 2009. 
Dan Li, Manuel Portugal Ferreira e Fernando Ribeiro Serra

\section{INTRODUCTION}

A growing stream of literature in both strategy and international management highlights the role of subsidiaries in knowledge generation and diffusion. Several authors argued that the primary reason for the multinational's existence is its capability to explore, transfer, and exploit technology across boundaries more effectively and efficiently than market mechanisms (e.g., BIRKINSHAW \& HOOD, 1998; CONNER \& PRAHALAD, 1996; KOGUT \& ZANDER, 1993). Innovation in multinational enterprises (MNEs) is no longer simply the responsibility of the corporate center (NOHRIA \& GHOSTAL, 1997). The corporate center was transformed from the "technology-creator" to the "technology-organizer" in its global operations (CANTWELL, 2001). Foreign subsidiaries not only serve the traditional function of adapting the parent MNE's technology to local market needs and providing technical support to local factories and customers (Cantwell, 2001; Doz, Bartlett, \& Prahalad, 1981; Johanson \& Vahlne, 1977), but have also become significant sources of technological development (Cantwell, 1991, 1995; Cantwell \& Janne, 1997; Ghoshal \& Bartlett, 1988; Bartlett \& Ghoshal, 1989).

However, subsidiaries' ability to act as technology vehicles that absorb local technologies and facilitate the development of MNEs' worldwide capabilities (Tallman \& Fladmoe-Lindquist, 2002) can be hindered in the presence of inter-subsidiary competitive behaviors. Such hindrance is likely to occur whenever loosely coupled organizational formats between the MNE's headquarters and the subsidiaries, and among the subsidiaries themselves, exist. In this situation, each subsidiary behaves autonomously and vies for its own interests. Despite being owned by the same parent (i.e., a hierarchical constraint), subsidiaries may act as relatively independent entities (Hedlund, 1986, 1993, 1994) from which some degree of multimarket competition may arise (Kalnins, 2004). That is, subsidiaries are subunits under an MNE's hierarchical control and are, simultaneously, firms competing in the open markets, and within the MNE. When coordination mechanisms fail, competitive behaviors are likely to prevail and inter-subsidiary technology transfer may not occur.

There is some evidence of the charter evolution of some subsidiaries indicating that these subsidiaries develop capabilities distinct from their headquarters and other subsidiaries (Birkinshaw \& Hood, 1998). Birkinshaw and Hood (1998, p. 782) acknowledged the potential for "mismatch between the subsidiary's capability profile and its official charter", but they did not theorize beyond an "internal competition for charters". However, competitive behaviors may emerge from this mismatch, which occurs because subsidiaries expand their geographic and/or product markets to utilize their new capabilities. Inter-subsidiary competition emerges not only when some subsidiaries develop beyond their mandated charters and develop competencies that overlap those of other subsidiaries, but also in the internal struggle for the headquarters allocation of resources. Yet, Birkinshaw and Hood did not acknowledge the potential for competitive behaviors, and instead bound the analysis in terms of the knowledge codifiability and stickiness, and motivations of the subsidiaries. However, inter-subsidiary competition may arise where one might expect to see cooperation.

Drawing from literature on multimarket competition, industrial organization, organizational models and design, and organizational knowledge and learning, we investigate intra-MNE cross-border technology transfer. Although extant research has examined various factors influencing technology transfer it has overlooked the importance of the cooperative or competitive relationships among subsidiaries for inter-subsidiary technology transfer. The extent to which subsidiaries exhibit cooperative or competitive behaviors will influence inter-subsidiary technology transfer. Specifically, we investigate the primary antecedents of subsidiaries' competitive or cooperative relationships within an MNE. We focus on how the strategy and structure characteristics of the MNE and the social ties

RAI - Revista de Administração e Inovação, São Paulo, v. 6, n. 1, p. 139-158, 2009. 
ARTICLES - Technology transfer within mnes: inter-subsidiary competition and cooperation

among its subsidiaries affect inter-subsidiary relationships, and how the resulting competitive or cooperative relationships among subsidiaries influence the cross-border technology transfer within the MNE. We do not focus on the type of technology being transferred [e.g., management-, product-, process-related technologies (Grosse, 1996)] because these do not induce a certain level of cooperation or competition, although it is possible that management-related technologies require a higher level of cooperation for effective transfer.

The remaining of this paper proceeds with a brief review of the literature on multimarket competition as the underlying conceptual rationale for the coexistence of competitive and cooperative behaviors among subsidiaries of the same parent MNE. The extent to which the relationships among subsidiaries are more competitive or cooperative determines the success of technology transfer. Then, we examine the effects of the MNE's structure, strategy and social relationships on inter-subsidiary cooperative relations. The paper concludes with implications and suggestions for additional inquiry.

\section{THEORETICAL DEVELOPMENT AND PROPOSITIONS}

Cross-border technology transfer by MNEs has been explored through various prisms. Technology transfer research has examined, for instance, how technology transfer affects MNEs foreign entry decisions (e.g., Isobe, Makino, \& Montgomery, 2000), how the patterns of technology transfer vary across countries (e.g., Phene \& Tallman, 2002), how the nature of technology impacts the transfer processes (e.g., Cantwell \& Mudambi, 2001), how a host country's economy, culture, and technological advancement influence the technology transfer processes (e.g., Cantwell, 2001), the vehicles for cross-border technology transfer (e.g. FDI, licensing, technical assistance contract, training contract) (e.g., Cantwell, 2001), and so forth. All these factors are likely to impact technology transfer as noted in existing research. Research on technology transfer is important because technologies are neither geographically concentrated nor locally bounded (Dunning, 1998). Technology is developed across the world and localized firms may benefit from being exposed to that knowledge (Kogut \& Zander, 1992). Hence, whether MNE subsidiaries succeed or fail in transferring technologies has important performance implications for the MNE as a whole. Dierickx \& Cool (1989) and Grant (1996), among many others, claimed that the firm's knowledge-base contributes most to its sustainable differentiation and consequently to its competitive advantage.

However, there is noticeably scarce research in international and strategic management specifically addressing intra-MNE (inter-subsidiary) flows of technology (e.g., Birkinshaw \& Hood, 1998; Hedlund, 1994; Tallman \& Fladmoe-Lindquist, 2002), and the transfer mechanisms among subsidiaries (Gupta \& Govindarajan, 2000; Teece, 1981). Namely, research is scarce on examining source-recipient relationships (i.e., relationships among subsidiaries), but these may be a major driver of cross border technology transfer. In this paper, we argue that subsidiaries fail to transfer technology in the presence of inter-subsidiary competitive pressures, and we examine the main hierarchical and relational factors that shape inter-subsidiary relationships.

The transfer of technologies among subsidiaries is subject to various factors. Figure 1 below depicts our conceptual model. As noted above, several factors have been researched, and their impact is known. For instance, the recipient's lack of absorptive capacity may hinder the transfer of technologies even though there is intention to transfer (e.g., Cohen \& Levinthal, 1990; Lane, Salk, \& Lyles, 2001; Szulanski, 1996), because the recipient subsidiary lacks the ability to understand, learn, and utilize the technology. The recipient subsidiary may lack, for example, knowledge of previous technologies because it did not invest in these in the past (Kogut, 1991); which may be particularly relevant for sequential and incremental technological advancements. The location of the recipient subsidiary may

RAI - Revista de Administração e Inovação, São Paulo, v. 6, n. 1, p. 139-158, 2009. 
also hinder its ability to recognize the value and relevance of the technology, and therefore the subsidiary may have no interest in the transfer. The location and technological sophistication of the source subsidiary also influences the success of technology transfer. In addition, the characteristics of the technologies to be transferred influence the success of technology transfer (Cantwell \& Mudambi, 2001; Lord \& Ranft, 2000). For example, the codification, ambiguity, and tacitness of the technology impacts on the transfer practices (Kogut \& Zander, 1993; Szulanski, 1996; Simonin, 1999; Polanyi, 1966). Finally, there may be other exogenous environmental variables such as the industry in which the subsidiaries operate (Teece, 1996; Tripsas, 1997; Tushman \& Anderson, 1986). For example, in fast changing industries MNE will likely seek to have technologies transferred directly from one subsidiary to another to speed learning and implementation in each location.

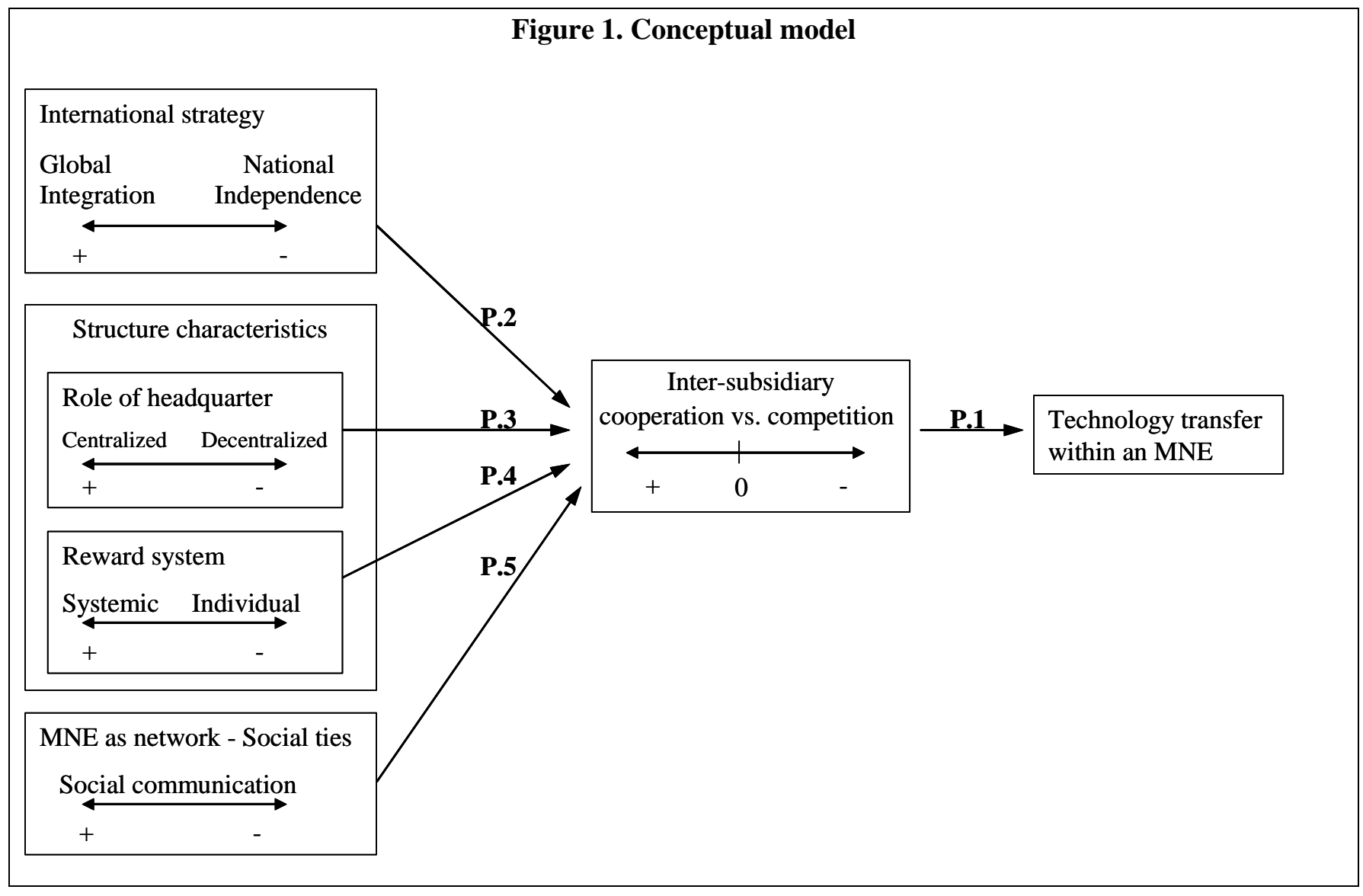

Although many variables have been examined to assess technology transfer, less research has focused on the importance of the relationships among the subsidiaries for technology transfer. In this paper, we focus on the source-recipient relationship and the extent to which they assume cooperative or competitive behaviors that will likely influence international technology transfer. We discuss the influence of strategy, structure and social interaction on the competitive/cooperative behaviors among subsidiaries as antecedents of the relationships among subsidiaries. Further, we discuss each of these as having independent effects; although we envision the possibility that there may be additive effects, we

RAI - Revista de Administração e Inovação, São Paulo, v. 6, n. 1, p. 139-158, 2009. 
ARTICLES - Technology transfer within mnes: inter-subsidiary competition and cooperation

do not propose specific additive relationships. The following section highlights that, in the absence of appropriate coordination, control, and integration systems, subsidiaries may be subject to multimarket competition and thus have lower technology transfer incentives.

\section{MULTIMARKET COMPETITION}

The concept of multimarket competition was initially developed to describe inter-firm competition. Multimarket competition has been primarily studied by industrial organization (IO) economists and game theorists to refer to "competitive situations in which the same firms compete against each other in multiple markets" (Jayachandran, Gimeno, \& Varadarajan, 1999: 46; Karnani \& Wernerfelt, 1985; Kalnins, 2004). Chen (1996) proposed a framework for competitor analysis incorporating market commonality and resource similarity, and recognized the asymmetry of market interdependence. Using a resource-based approach, Chen (1996) defined market commonality as "the degree of presence that a competitor manifests in the markets it overlaps with the focal firm", whereas resource similarity was defined as "the degree to which a given competitor possesses strategic endowments comparable to those of the focal firm in both type and quantity". The extent of market commonality and resource similarity shared with competitors drive, at least partly, firms' strategic competitive decisions. In the context of multimarket competition, Jayachandran et al. (1999: 51) also recognized the potential for collusion among market players (particularly in oligopolistic market structures) and defined mutual forbearance as "tacit collusion as a consequence of firms competing in many markets and the resulting increase in their interdependence" (see also Haveman \& Nonnemaker, 2000). This is particularly important for MNEs because the relationships among subsidiaries are likely to be one of the most important factors in constructing MNE advantages. For instance, subsidiaries' interaction is important to understand how MNEs are able to learn from locating in knowledge clusters, given that a core assumption of MNEs existence is that they will be able to leverage the knowledge and technologies acquired in some locations to other locations.

Viewing the MNE as a "network" structure integrating differentiated units (Cantwell \& Mudambi, 2001; Ghoshal \& Bartlett, 1990; Gupta \& Govindarajan, 1991; Hedlund, 1986, 1994; Nohria \& Ghoshal, 1997), we extend the concept of multimarket competition to within the MNE. We argue that multimarket competition may be observed in intra-MNE (i.e., inter-subsidiary) relations, as subsidiaries compete with each other for markets and parental resources. Subsidiaries are relatively free agent operating within certain parent-defined parameters (i.e., an hierarchy) but integrated in a fairly loose manner [e.g., Hedlund's (1986) heterarchy, or Nohria \& Ghoshal's (1997) network model]. Furthermore, some subsidiaries often have proactive roles, as noted by Birkinshaw (2001, p. 393) "many firm resources and capabilities are actually developed at the subsidiary level" because it is the subsidiary's manager who has the local contacts and the intimate knowledge of local activities, not the executives at the headquarters. For example, subsidiaries located in clusters of excellence may be more autonomous from the headquarters (Hedlund, 1986) but if they engage in competitive behaviors with sibling subsidiaries technology transfers among these subsidiaries may not occur.

Notwithstanding, there are fundamental differences when extending the concept of multimarket competition between independent firms to inter-subsidiary relationships. The existence of headquarters distinguishes inter-subsidiary competition (Haveman \& Nonnemaker, 2000) from that among independent firms. For example, competition among independent firms is not subject to hierarchical pressures, and independent firms enjoy high autonomy to select the competitive strategies that best fit their competitive landscapes. However, subsidiaries need to balance the potential hazards and benefits from integration, coordination, and control. The hierarchy (ownership control) is at the heart of such

RAI - Revista de Administração e Inovação, São Paulo, v. 6, n. 1, p. 139-158, 2009. 
integration, and the deployment of scarce resources is a distinct task, but the geographic distance underlying inter-subsidiary interaction entails various market and management difficulties. Nevertheless, the differences between inter-firm and intra-MNE competition do not attenuate a multimarket competition scenario, rather these dissimilarities exaggerate the scenario described in multimarket competition theories. Subsidiaries need to pay more attention to the co-existence of competition and cooperation with other sister subsidiaries, than an independent firm would be required to do. Cooperative relationships among subsidiaries are associated with technology transfer success while internal competition with transfer hindrance.

Why may some subsidiaries compete? We note three main reasons for the existence of intersubsidiary competition. First, inter-subsidiary competition may stem from the rivalry for resources from the parent firm. Subsidiaries compete not only in the external market for scarce resources as independent firms do, but also in the internal market for parental resources. The greater the extent to which subsidiaries compete for similar resources, the more their propensity to engage in competitive behaviors.

Second, inter-subsidiary competition may originate from related product and geographic diversification strategies. In the absence of tight integration and coordination, autonomous subsidiaries enlarge their pool of capabilities (Birkinshaw, 1996) and may seek placement for their technologies and products outside their original geographic market. This may create a situation of market commonality, or overlap with the market of other subsidiaries, and parallels Birkinshaw and Hood's (1998) "charter change" which originates when some subsidiaries develop beyond their mandated charters and grow competencies that supersede those of other subsidiaries. A competitive attack by one subsidiary in the major market of the other subsidiary is then likely to generate a reaction of the latter in the first subsidiary's domain (Jayachandran et al., 1999). If the markets of competing subsidiaries overlap in multiple locations these subsidiaries are held in multimarket competition, and a competitive game unfolds where one may stereotypically expect to observe inter-subsidiary cooperation.

Finally, inter-subsidiary competition may be rooted in an under-defined specialization of each subsidiary. When the rights and responsibilities, the goals and market scope of each subsidiary are not clearly defined conflicts may arise. Each subsidiary vies for its own interests, and to the extent that these interests overlap competition among subsidiaries intensifies (a phenomenon that Fauli-Oller \& Giralt (1995) labeled as "negative spillover" among MNE subsidiaries). Thus, inter-subsidiary competition may emerge from resource similarities and originate competition, regardless whether or not there is market commonality.

The principal belief that MNEs possess superior resources, or capabilities, to overcome the traditional liabilities of foreignness in host locations (Hymer, 1976) is based on the assumption that MNEs are able not only to diffuse their stock of technologies to the subsidiaries, but also to convey the technologies developed locally by each subsidiary to other MNE progenies (Kogut \& Zander, 1993). It is worth noting at the outset that any one subsidiary may benefit from cooperating in the transfer of technology to other subsidiaries, and to coordinate with each other and with headquarters for various reasons. For example, the operations of one subsidiary may benefit from inputs from other subsidiaries, and foster an efficient system of subsidiary specialization and interdependence (Birkinshaw, 1996; Birkinshaw \& Ridderstrale, 1999). By pooling together assets, resources, and capabilities subsidiaries may have access to technologies, learning experiences, resources and capabilities that none possesses independently, and develop absorptive capacity for future technology inflows. In addition, technology sharing fosters a trustworthy and cooperative profile among subsidiaries, which will likely lead to future inflows of technology. Thus, by cooperating with other siblings each subsidiary increases the likelihood that others will cooperate with it, and hence enlarges the pool of technologies it may draw

RAI - Revista de Administração e Inovação, São Paulo, v. 6, n. 1, p. 139-158, 2009. 
ARTICLES - Technology transfer within mnes: inter-subsidiary competition and cooperation

upon.

Proposition 1. Inter-subsidiary cooperative relationships are more likely to promote international technology transfers within an MNE, in contrast to inter-subsidiary competitive relationships.

\section{CHARACTERISTICS OF MNES AND INTERNAL TECHNOLOGY TRANSFER}

MNEs exist because of their ability to transfer and exploit technology across geographic locations more effectively and efficiently than market mechanisms (CONNER \& PRAHALAD, 1996; KOGUT \& ZANDER, 1993). Kogut and Zander (1993) explain the existence of MNEs by their relative efficiency in the transfer of tacit knowledge (i.e., knowledge that is difficult to codify, based on routines, and embedded in the human capital) compared to market mechanisms (NELSON \& WINTER, 1982; WILLIAMSON, 1985). Furthermore, the MNE is not simply a mechanism through which costs are reduced, but rather a vehicle for exploiting existing technologies, and for the recombination of these technologies to produce new technologies (KOGUT \& ZANDER, 1992; 1993). In the following sections we examine how an MNE's international strategy, two major aspects of its organizational structure (i.e., the role of the headquarters, and the reward system), and the view of MNEs as networks (inter-subsidiary social communication), promote, or obstruct, inter-subsidiary technology transfer.

\subsection{MNE STRATEGY}

In the early 1980s, Prahalad (1976), Doz (1980), Doz, Bartlett and Prahalad (1981), and Prahalad and Doz (1987) developed the Integration-Responsiveness framework (I-R), which shifted the analysis of organization design from formal structures to managerial processes. This framework classifies four types of international strategies utilized by MNEs along two dimensions: local responsiveness, and global integration. The I-R model proposes the following typology: international, multinational, global, and transnational strategies. Porter's (1986) coordination-configuration model finds some parallelism with the I-R framework. Both models provide a useful tool for the analysis of firms' international strategies.

When both the pressures for local responsiveness and for global integration are low, an international strategy is more likely to be implemented. An international strategy does not demand local responsiveness, and the firm's foreign strategies are supported in the replication of what seems to have worked well at home. The subsidiaries are autonomous from each other and the only technology transfer channel is from the parent to the subsidiaries. A multinational strategy entails local responsiveness as an attempt to overcome markets' idiosyncrasies. The firm is composed of fairly autonomous subsidiaries that are responsive to the host country market in which they are located (Bartlett \& Ghoshal, 1988). Under a multinational strategy, there is no clear need for inter-subsidiary cooperation; and the desire to grow may motivate local subsidiaries to compete with subsidiaries at other geographic locations. Therefore, inter-subsidiary competition is likely to be intense when compared to the competitive intensity among subsidiaries of MNEs pursuing an international strategy. Both international and multinational strategies require little integration among subsidiaries, and the subsidiaries' operations tend to be more locally independent.

Both global and transnational strategies deal with high pressure for worldwide integration. Global strategies respond to a view of the world as a single marketplace in which all consumers are alike (Leavitt, 1983). MNEs commercialize standardized products worldwide to take advantage of global economies of scale and scope, supporting their competitive advantages in tightly coupled

RAI - Revista de Administração e Inovação, São Paulo, v. 6, n. 1, p. 139-158, 2009. 
subsidiaries and coordination and control mechanisms. MNEs adopting global strategies concentrate production in low-cost countries, and use global marketing and advertising to reach their customers. The high reliance among subsidiaries on the same value chain makes competition among subsidiaries relatively weak for MNEs pursuing a global strategy. Firms pursuing transnational strategies recognize cost advantages of economies of scale and scope, but are sensitive to differences in national markets. MNEs pursuing a transnational strategy seek to achieve simultaneously global efficiency and local responsiveness with the resources and activities dispersed but specialized. Transnational strategies are characterized by a high degree of inter-subsidiary interdependence (i.e., a high volume of intra-MNE trade flows) that results in relatively weak inter-subsidiary competition. Subsidiaries highly responsive to local markets are expected to create new technologies and transfer them to other subsidiaries and to the headquarters. Taking the MNE as a whole we expect less competition and more coordination displayed among subsidiaries of firms pursuing global or transnational strategies due to the higher level of integration and coordination exhibited.

Proposition 2. Inter-subsidiary cooperation will be higher and competition lower in MNEs pursuing globally integrated strategies than for firms pursuing nationally independent strategies.

Rather than categorizing MNEs' internal and external requirements some scholars called for the examination of MNEs as networks of differentiated subsidiaries (Ghoshal \& Bartlett, 1990; Gupta \& Govindarajan, 1991; Hedlund, 1994; Nohria \& Ghoshal, 1997) whereby subsidiaries have specialized roles. For example, Palmer, Jennings and Zhou's (1993, p. 103) statement that organizations are "arenas in which coalitions with different interests and capacities for influence vie for dominance" seems to suit the network approach, but also highlights the potential for competitive behaviors. Similar to the I-R framework, network researchers also argue that MNEs stressing global integration experience more internal technology flows than MNEs requiring a relatively lower integration. Higher integration strategies are more likely to be associated with more extensive inter-subsidiary cooperation.

\subsection{MNE STRUCTURE}

MNEs are heterogeneous entities composed of functionally differentiated subsidiaries pursuing specific goals and interests (Nohria \& Ghoshal, 1997). The organizational structure that integrates, coordinates, and controls subsidiaries' actions is essential to ensure that subsidiaries are driven by company-wide interests rather than by local priorities (Birkinshaw, 2001). Lawrence and Lorsch (1967) suggested that organizational subunits adapt differentially to their specific environmental landscapes, leading the authors to conclude that organizations encountering heterogeneous environments need more structural differentiation and integration to succeed. Thus, the organizational structure influences intersubsidiary behaviors, and, ultimately, technology transfers.

Role of MNE headquarters. Cantwell (2001) argued that the role of MNEs' headquarters has shifted from "technology creator" to "technology organizer". Subsidiaries, and not the headquarters, are increasingly responsible for generating and transferring new technologies. Fast changing environments require speed in transferring and adopting new technologies, which is more swift and efficient when subsidiaries transfer directly to other subsidiaries. Thus, direct technology transfers from headquarters to subsidiaries are declining and inter-subsidiary transfers are increasing. However, in contrast to technology transfers within domestic firms, where both the source and the recipient units are proximally located, are likely aware of each other's capabilities and markets, and are tied by cohesive, personal, relationships the transfer of technologies may be more difficult for MNEs because subsidiaries are geographically dispersed (Strang \& Soule, 1998; Wejnert, 2002). Subsidiaries that are distant from each other, separated by cultural barriers, technological distances (Phene \& Tallman,

RAI - Revista de Administração e Inovação, São Paulo, v. 6, n. 1, p. 139-158, 2009. 
ARTICLES - Technology transfer within mnes: inter-subsidiary competition and cooperation

2002), and subject to communication hazards may be unaware of other subsidiaries' achievements or needs, making inter-subsidiary technology transfer a more arduous endeavor (Wejnert, 2002). Notwithstanding, by increasing decentralization of decision making to lower levels (i.e., to the subsidiary) the headquarters promote learning and cooperation among subsidiaries.

The headquarters, as technology organizer, influence inter-subsidiary technology transfer. First, the headquarters have hierarchical (or ownership) relations over the subsidiaries. Equity ownership control is a legitimate authority that a firm has over its assets (Hennart, 1988; Mjoen \& Tallman, 1997), and provides headquarters with the ability to control inter-subsidiaries' relationships. For example, converting competitive behaviors in cooperative ties. Second, the headquarters have informational advantages over sibling subsidiaries (Zander \& Solvell, 2000). Positioned centrally in an MNE's information network, the headquarters operates as the "architect" (Tallman \& Fladmoe-Lindquist, 2002) for inter-subsidiary technology exchanges, regulating technologies in transit and recombining technology exchanges among subsidiaries. Third, the headquarters control de allocation of resources among subsidiaries, and hence influence subsidiaries' strategic choices and behaviors. The headquarters centralize both tangible and intangible resources on which the subsidiary may depend to develop specific strategic factors (e.g. Tyco's headquarters takes all subsidiary's profits and the subsidiary is absolutely dependent on the parent firm - Hill \& Jones, 2001). Resource independent subsidiaries are less dependent on headquarters' resources, and are more likely to compete with other subsidiaries, rather than exhibiting forbearance (collusive or cooperative) behaviors (Haveman \& Nonnemaker, 2000). Therefore, through centralization, headquarters guarantee inter-subsidiary transfers, and by decentralizing, headquarters promote inter-subsidiary competition.

Thus, the degree of decentralization is likely to be negatively related to the propensity to transfer locally developed technologies. Subsidiaries of MNEs with a decentralized, loose, structure compete for their own interests. For example, larger decentralization may lead subsidiaries to expand their product and market mandate, and compete in other subsidiary's focal market(s). Conversely, MNEs pursuing more extensive centralization and control over inter-subsidiary relationships are more capable of overseeing competition, and encourage inter-subsidiary cooperation, which will likely result in more intra-MNE technology transfers.

Proposition 3. Inter-subsidiary cooperation will be higher and competition lower in MNEs with more extensive centralization of control at the headquarters than in MNEs with less extensive centralization of control at the headquarters.

Reward system. The reward system is an internal mechanism to achieve congruence of objectives and actions among subsidiaries and headquarters. March and Simon (1958), for example, noted that incentive systems (or reward systems) impact individuals' behavior. Gupta and Govindarajan (2000) argued that a reward system based on the performance of the whole MNE (i.e., a systemic reward system) would motivate technology outflows (i.e., the transfer of locally developed technologies to other subsidiaries) but de-motivate technology inflows. Conversely, a reward system based only on each subsidiary's performance (i.e., an individually based reward system) motivates the subsidiary's manager to seek and learn advanced technologies. Some difficulties in designing an effective reward system may be briefly noted. For example, although some studies suggest that a reward system based on the whole MNE's performance (i.e., a systemic reward systems) motivates the source subsidiary to transfer technologies to other subsidiaries, there may be free-riding behaviors by the source subsidiary that may deter any technology outflow. That is, the source subsidiary may not

RAI - Revista de Administração e Inovação, São Paulo, v. 6, n. 1, p. 139-158, 2009. 
commit to the technology outflow because whether the recipient subsidiary uses efficiently the technology does not affect the source's performance evaluation. Therefore, headquarters face a reward design dilemma -- the reward system needs to promote simultaneous incentives for technology transfer for the source and the recipient subsidiaries.

Parallel to our distinction between systemic and individually-based reward systems is the identification of two basic reward systems into objective and subjective (Golden \& Ma, 2002; Hill et al., 1992; Hoskisson \& Hitt, 1988). To alleviate performance ambiguity problems when competition and cooperation coexist within M-form organizations Hill et al. (1992) recommended expanding the breadth of information available to corporate management (i.e., cooperation between units can be encouraged when subjective measures of division performance are considered in corporate resource and reward allocation decisions). Such evaluation systems ensure that the "business unit managers... who cooperate with their counterparts in other business unit...will not be punished if their performance falls short according to conventional measures of financial performance" (Golden \& Ma, 2002, p. 14). Therefore, a systemic, or subjective, reward system encourages inter-subsidiary cooperation, and values collaborative behaviors aimed at increasing other subsidiaries' performance, and the overall performance of the MNE. A systemic reward model preempts internal competition because it bases the evaluation of a focal subsidiary on its contributions to the whole MNE.

Individually-based reward systems are based on the individual subsidiary's performance. In contrast to systemic reward systems, individual reward systems are likely to generate inter-subsidiary competition (Galbraith, 1973) because subsidiaries will tend to focus on improving their own performance, rather than coordinating with the other subsidiaries. For example, Mascarenhas (1984) noted that an individually-based reward system based on financial measures of MNE subsidiaries does not generate inter-subsidiary cooperation. A focus on individual performance evaluations motivates subsidiaries to search actively for advanced technologies for their own use and may lead to a competitive game in which each subsidiary is interested in technology inflows (i.e., absorbing) but not in outflows (i.e., conceding). This competition may provide some explanation for why any technology management advantage of MNEs, as assumed in previous studies, may be unrealized. Thus, individual reward systems based on a focal subsidiary's performance are more effective if little inter-subsidiary cooperation is required. Conversely, a systemic reward system is more likely to promote intersubsidiary cooperative efforts such as technology transfers.

Proposition 4. Inter-subsidiary cooperation will be higher and competition lower in MNEs pursuing a systemic reward system (based on the overall contribution to the MNE) than in MNEs pursuing an individual reward system (based on the individual performance of each subsidiary).

\subsection{THE MNE AS A NETWORK}

MNEs that expand internationally based on a network of independent, autonomous, and self-sufficient subsidiaries may face a substantial challenge in achieving effective inter-subsidiary coordination. In this case, either the subsidiaries do not communicate enough among themselves (e.g., not transferring technologies, best practices, or local knowledge), or each subsidiary vies for its own interests in partial disregard for the interests of the overall MNE. For example, Philips has been noted (Bartlett \& Ghoshal, 1988) as being unable to assume market leadership despite its innovative activity. We note two main factors for Phillips' lack of market success: (1) the need to assure the flow of technologies from the subsidiaries to the overall organization through management and strategic

RAI - Revista de Administração e Inovação, São Paulo, v. 6, n. 1, p. 139-158, 2009. 
ARTICLES - Technology transfer within mnes: inter-subsidiary competition and cooperation

processes, and (2) the importance of having responsibility, accountability, and communication mechanisms to foster transfers among subsidiaries.

The network model of the MNE (or heterarchy, according to Hedlund, 1986) relies on the view of loosely tied subsidiaries that have the freedom to develop their own resource positions (Birkinshaw \& Hood, 1998; Nohria \& Ghoshal, 1997). A network structure reflects a division of labor and knowledge, and some interdependence among subsidiaries since each subsidiary is dependent on the others for specialized inputs. Furthermore, the network model entails evolution at the subsidiary level (Birkinshaw \& Hood, 1998) whose mandates may evolve as the subsidiary develops valuable, rare, inimitable, and non-substitutable resources (Barney, 1991; Penrose, 1959; Wernerfelt, 1984), dynamic capabilities (Nelson \& Winter, 1982; Teece, Pisano, \& Shuen, 1997), or architectural capabilities (Tallman \& Fladmoe-Lindquist, 2002). Birkinshaw \& Hood (1998), thus, noted that the accumulation of resources and capabilities at the subsidiary reduces the dependence of the focal subsidiary on the other subsidiaries of the MNE (see also Gupta \& Govindarajan, 1991; Pfeffer \& Salancik, 1978; Prahalad \& Doz, 1987). In sum, some subsidiaries charter evolves, and these subsidiaries become more loosely tied to the headquarters' directives and control (Birkinshaw, 1995). The MNE may need to focus on fostering relational ties and communication to promote inter-subsidiary cooperation.

Inter-subsidiary social communication decreases the potential for (multimarket) competitive behaviors, and rather promotes cooperation. Departing from previous studies defining inter-subsidiary communication as the formal report system of financial or production information, we emphasize the informal and social communication relationships among subsidiaries and subsidiaries' managers. Social communication increases inter-subsidiary awareness of other subsidiaries' status, product lines 1 , market plans, pool of technologies, retaliatory ability, and promotes inter-subsidiary familiarity 2 possibly contributing to develop social ties among subsidiary managers (Chen \& Miller, 1994; Jayachandran et al., 1999). Multimarket competition literature considers awareness as an essential prerequisite for action (Chen, 1996). The higher the awareness the easier it is for subsidiaries to recognize opportunities for technology transfer. Thus, social communication decreases the potential for market entry in the other subsidiaries' focal markets. Inter-subsidiary social communication also promotes integration (Lorsch \& Lawrence, 1965) and the socialization of the subsidiaries into the overall MNE's values, mission, and objectives. Furthermore, inter-subsidiary social communication decreases technologies' causal ambiguity, increases subsidiaries ability to evaluate, learn, and utilize similar technologies, and identify opportunities for technology transfer. Hedlund (1994), for example, emphasized lateral communication across the whole MNE and the catalytic, or architectural, role of top managers in the process. Inter-subsidiary social communication promotes cooperation, and may be sponsored through formal organizational programs such as managers' rotation, meetings, conferences, joint-task forces, and interlocking directorates (Ghoshal \& Bartlett, 1988; Strang \& Soule, 1998). These programs are typically designed to foster inter-subsidiary cooperation and promote cohesive ties among subsidiaries' managers. Social communication increases not only inter-subsidiary familiary, and trust among managers, but also promotes an organizational culture encouraging cooperation. An example may be found in the management exchange programs at Asean Brown Brovery (ABB) and the constant flow of an elite cadre of 500 top managers among subsidiaries (Hill \& Jones, 2001). In sum, intersubsidiary social communication works to preempt competitive behaviors and is likely to facilitate transfers.

\footnotetext{
${ }^{1}$ The more extensive the product lines the more occasions for product-market overlap exist.

${ }^{2}$ Familiarity assumes some degree of coordination because firms become aware of others' capabilities, resources and strategic actions. Thus, it is one of the mechanisms for mutual forbearance.
}

RAI - Revista de Administração e Inovação, São Paulo, v. 6, n. 1, p. 139-158, 2009. 
Proposition 5. Inter-subsidiary cooperation will be higher and competition lower in MNEs with more inter-subsidiary social communication than in MNEs with less inter-subsidiary social communication.

It is noteworthy that incentives for technology transfer, such as promotion of inter-subsidiary communication or reward systems, aim at overcoming potential competitive behaviors or, at least, fostering inter-subsidiary cooperative dynamics. It is the headquarters that may override competitive pressures through the exercise of control, coordination, and integration (i.e., through the use of hierarchy). In sum, inter-subsidiary international technology transfer is subject to the influences of the MNE's international strategy, organizational structure and relational attributes. Multinationals can no longer take for granted that their subsidiaries absorb local technologies and pool local resources to create and transfer new technologies. The next section develops a final discussion and concluding remarks.

\section{DISCUSSION AND CONCLUSION}

The extent of competitive and cooperative behaviors among subsidiaries seems to be dependent on the organizational model, coordination, and control and integration of activities dispersed worldwide. We used the concept of multimarket competition to highlight that under certain conditions multimarket competition may arise among MNE subsidiaries. The potential to bring game theory into international strategy research should not be disregarded. We examined technology transfer in the context of potential competitive pressures between subsidiaries, in contrast to the transfers when subsidiaries cooperate, as is generally assumed in the majority of existing research. When the subsidiaries are managed as autonomous entities (e.g., heterarchy or network models) pursuing their own goals, there is a possibility that we may observe subsidiaries growing and diversifying into related and unrelated product and geographic markets, and competing with their sister subsidiaries in their focal markets. This seems to have been the case with some of ABB's subsidiaries (see Hill \& Jones, 2001).

Although this paper is conceptual, and we do not test the propositions advanced, a number of possible implications for managers may be drawn. Managers need to understand whether technology transfer between subsidiaries is critical for competitive advantage and the importance of cooperative or competitive behaviors among subsidiaries to access and develop technologies. When technology transfer is important managers need to evaluate the extent to which subsidiaries are cooperative or competitive and align strategy, structure, and social relationships among subsidiaries to maximize transfers. At a more specific level, while the current trend has been towards non-hierarchical management models, such as the multidivisional, the M-form, and the network models, these organizational forms may have a negative impact on the extent to which MNEs are able to learn and diffuse internally locally acquired technologies. The current trend has also been towards defining systemic reward systems, and this paper supports this current trend. However, managers may need, at a minimum, to increase monitoring, or build social communication mechanisms to promote transfers. Communication, however, must be more than formal reporting in order to facilitate cooperation; it must add social and informal communication and tie-building mechanisms. That is, technology transfer does not occur automatically, as seems often assumed in extant research. MNEs need to manage the transfer process, and create a corporate culture and transfer mechanisms that ensure cooperation, and thus, ensure effective international technology transfers.

Managers may further consider a configurational model supported in specialized centers of responsibility to assure inter-subsidiary technology transfer. For example, Ericsson developed a

RAI - Revista de Administração e Inovação, São Paulo, v. 6, n. 1, p. 139-158, 2009. 
ARTICLES - Technology transfer within mnes: inter-subsidiary competition and cooperation

model whereby each subsidiary is specialized and responsible for the technological innovations in particular areas (e.g. transmission systems, mobile phones, digital switches, and software development). These subsidiaries are also responsible to transfer the technology to headquarters and to other subsidiaries. In sum, an essential element to ensure inter-subsidiary technology transfer relies on an organizational configuration based on a system of reciprocal dependence among subsidiaries (i.e., a network model of integrated and cooperative subsidiaries).

An empirical test of the propositions we advanced seems a fruitful avenue for additional research. The search for empirical support will benefit technology transfer literature and disclose other dimensions that impact intra-firm technology transfers. The operationalization of the major constructs (i.e., MNE strategy, MNE structure, inter-subsidiary competition, inter-subsidiary cooperation, and internal technology transfer) may rely on existing scales and surveys. Birkinshaw (2001), for example, offers a good template to operationalize global integration, and but other studies exist that offer validated scales for inter-subsidiary relationships, internal technology transfer, and some organizational structure features of the MNE. Measures for internal technology transfer may be designed in terms of actual outcomes such as the occurrence and success of previous transfers, and be based on Kostova's work (1997). Additionally, interviews may be conducted to assess the intention to transfer and whether technology transfer was a subsidiary strategic decision or a corporate policy. Finally, empirical studies may need to control for cultural distance, the MNE home base, the absorptive ability of the subsidiary, and government regulations (Navaretti \& Tarr, 2000).

We conceptualized the four main factors (see left hand boxes in figure 1) as having independent effects, maybe additive. Future research may explore whether there may be interactions and moderation effects among them. We do not suggest moderation effects because we do not find theoretical support for the extent and direction of such moderating effects. Notwithstanding, it seems reasonable to suggest that cooperation may exist even if the firm pursues a globally integrated strategy and the subsidiaries are highly socially embedded (extensive social communication). Bartlett and Ghoshal's (1989) discussion of Philips is illustrative: Philips has been noted to seek larger integration among subsidiaries but the social ties or social embeddedness (Granovetter, 1985) between subsidiaries' managers (which are largely Dutch expatriates) seem to have prevented larger integration. Hence, we discuss each variable as independent with possibly additive effects.

Future research is warranted on the extent to which cooperation and competition exist as a continuum or rather as related but somewhat different dimensions. For example, cooperation and competition may co-exist simultaneously, such as in the situations where subsidiaries cooperate in R\&D but compete for market share. Does this mean that competition and cooperation are orthogonal? In our conceptualization we allowed for a neutral point of simultaneous low, or non-existent, competition and cooperation. Nevertheless, further research is needed to clarify this issue. Other research avenues entail investigating how transfer capabilities affect technology transfer flows among subsidiaries even within a competitive game. The capability to transfer technology depends not only on the recipient's absorptive capacity but also on the technology's codifiability, sophistication, and ease of transfer within the MNE. Investigating how subsidiaries combine their own technological uniqueness with new technologies from other subsidiaries is interesting for work on the knowledge multinational. Finally, we may research how the type of technology (e.g., product, process, or management) influences both the transfer process and success. For instance, transfer of management technologies may be subject to higher inter-subsidiary competition than product technologies.

To conclude, in this paper we suggested that international and strategic management research have a promising avenue in the study of how some subsidiaries may develop competitive behaviors that hinder the overall MNE from fully exploiting the capacity to absorb local knowledge. This is in

RAI - Revista de Administração e Inovação, São Paulo, v. 6, n. 1, p. 139-158, 2009. 
contrast to extant theory and research that seeks to explain why and how technology transfers occur within multinational enterprises but has generally assumed inter-subsidiary cooperation. A current explanation for the existence of multinational enterprises is that MNEs are able to capture technologies and knowledge that are bounded to a locality such as an industry cluster (Porter, 1998), and internalize that knowledge (Kogut \& Zander, 1993). We advanced that the success of inter-subsidiary technology transfer depends on the extent to which the relationships among subsidiaries are competitive or cooperative. Furthermore, while technology transfer studies have not paid enough attention to social embeddeness and internal structural characteristics such as the reward systems, these may be important drivers of competitive pressures among subsidiaries and therefore have an impact on the MNE's ability to learn. Hierarchical and social relational factors drive the potential for inter-subsidiary (multimarket) competition that originates from the overlap on the subsidiaries' products, technologies, and market portfolios. Inter-subsidiary competition seems to be a significant challenge as a growing number of studies and authors suggest flexible and network-like organizational models for the MNE.

\section{REFERENCES}

BARNEY, J. Firm resources and sustained competitive advantage. Journal of Management, 17(1): 99-120, 1991.

BARTLETT, C., GHOSHAL, S. Organizing for worldwide effectiveness: The transnational solution. California Management Review, Fall: 54-74, 1988.

BARTLETT, C., GHOSHAL, S. Managing across borders: The transnational solution. Boston, Mass.: Harvard Business School Press, 1989.

BIRKINSHAW, J. Transnational corporations in Southeast Asia: An institutional approach to industrial organization. Journal of International Business Studies, 26(4): 904-906, 1995.

BIRKINSHAW, J. How multinational subsidiary mandates are gained and lost. Journal of International Business Studies, 27(3): 467-495, 1996.

BIRKINSHAW, J. Entrepreneurship in multinational corporations: The characteristics of subsidiary initiatives. Strategic Management Journal, 18(3): 207-229, 1997.

BIRKINSHAW, J. Strategies for managing internal competition. California Management Review, 44(1): 21-38, 2001.

BIRKINSHAW, J., HOOD, N. Multinational subsidiary evolution: Capability and charter change in foreignowned subsidiary companies. Academy of Management Review, 23(4): 773-795, 1998.

BIRKINSHAW, J., RIDDERSTRALE, J. Fighting the corporate immune system: A process study of subsidiary initiatives in multinational corporations. International Business Review, 8: 149-180, 1999.

RAI - Revista de Administração e Inovação, São Paulo, v. 6, n. 1, p. 139-158, 2009. 
ARTICLES - Technology transfer within mnes: inter-subsidiary competition and cooperation

CANTWELL, J. The theory of technological competence and its application to international production. In D. G. McFetridge (Ed.), Foreign Investment, Technology and Economic Growth, Calgary: University of Calgary Press, 1991.

CANTWELL, J. The globalization of technology: What remains of the product cycle model? Cambridge Journal of Economics, 19: 155-179, 1995.

CANTWELL, J. Innovation and information technology in MNE. In T. L. Brewer (Ed.), The Oxford Handbook of International Business, Oxford, UK: Oxford University Press, 431-456, 2001.

CANTWELL, J., JANNE, O. Technological globalisation and innovative centers: The role of corporate technological leadership and locational hierarchy. Discussion Papers in International Investment \& Management, 1997.

CANTWELL, J., MUDAMBI, R. 2001. Multinational enterprises and competence-creating knowledge flows: A theoretical analysis. In T. Pedersen (Ed.), Governing Knowledge in the MNC, Oxford, UK: Oxford University Press, 2004.

CHEN, M.-J. Competitor analysis and interfirm rivalry: Toward a theoretical integration. Academy of Management Review, 21(1): 100-134, 1996.

CHEN, M., MILLER, D. Competitive attack, retaliation and performance: An expectancy-valence framework. Strategic Management Journal, 15(2): 85-102, 1994.

COHEN, W., LEVINTHAL, D. Absorptive capacity: A new perspective on learning and innovation. Administrative Science Quarterly, 35(1): 128-152, 1990.

CONNER, K., PRAHALAD, C. K. A resource-based theory of the firm: Knowledge versus opportunism. Organization Science, 7(5): 477-501, 1996.

DIERICKX, I., COOL, K. Asset stock accumulation and sustainability of competitive advantage. Management Science, 35: 1504-1511, 1989.

DOZ, Y. Strategic management in multinational companies. Sloan Management Review, 21(2): 27-46, 1980.

DOZ, Y., BARTLETT, C., PRAHALAD, C. K. Global competitive pressures and host country demands: Managing tensions in MNCs. California Management Review, 23: 63-73, 1981.

DUNNING, J. Location and the multinational enterprise: A neglected factor? Journal of International Business Studies, 29(1): 45-66, 1998.

Fauli-Oller, R., Giralt, M. Competition and cooperation within a multidivisional firm. Journal of Industrial Economics, 43(1): 77-99, 1995.

GALBRAITH, J. Designing complex organizations. Reading, Mass.: Addison-Wesley Pub. Co., 1973

RAI - Revista de Administração e Inovação, São Paulo, v. 6, n. 1, p. 139-158, 2009. 
GHOSHAL, S., BARTLETT, C. The multinational organization as an interorganizational network. Academy of Management Review, 15(603-625), 1990.

GHOSHAL, S., BARTLETT, C. Creation, adoption, and diffusion of innovations by subsidiaries of multinational corporations. Journal of International Business Studies, 19(3): 365-388, 1988.

GOLDEN, B., MA, H. Mutual forbearance: The role of intra-firm integration and rewards. Working Paper, University of Western Ontario, 2002.

GRANT, R. Prospering in dynamically-competitive environments: Organizational capability as knowledge integration. Organization Science, 7(4): 375-387, 1996.

GRANOVETTER, M. Economic action and social structure: The problem of embeddedness. American Journal of Sociology, 91(3), 1985.

GROSSE, R. International technology transfer in services. Journal of International Business Studies, 27(4): 781-800, 1996.

GUPTA, A., GOVINDARAJAN, V. Knowledge flows and the structure of control within multinational corporations. Academy of Management Review, 16(4): 768-792, 1991.

GUPTA, A., GOVINDARAJAN, V. Knowledge flows within multinational corporations. Strategic Management Journal, 21(4): 473-496, 2000.

HAVEMAN, H., NONNEMAKER, L. Competition in multiple geographic markets: The impact on growth and market entry. Administrative Science Quarterly, 45: 232-267, 2000.

HEDLUND, G. The hypermodern MNC: A heterarchy? Human Resource Management, 25: 9-36, 1986.

HEDLUND, G. Assumptions of hierarchy and heterarchy: An application to the multinational corporation. In S. Ghoshal, \& D. E. Westney (Eds.), Organization theory and the multinational corporation, London: Macmillan, 211-236, 1993.

HEDLUND, G. A model of knowledge management and the N-form corporation. Strategic Management Journal, 15(Special Issue): 73-90, 1994.

HENNART, J.-F. A transaction costs theory of equity joint ventures. Strategic Management Journal, 9(4): 361-374, 1988.

HILL, C., JONES, G. Strategic management: An integrated approach (5th ed.). Boston, MA: Houghton Mifflin, 2001.

HILL, C., HITT, M., HOSKISSON, R. Cooperative versus competitive structures in related and unrelated diversified firms. Organization Science, 3(4): 501-521, 1992.

RAI - Revista de Administração e Inovação, São Paulo, v. 6, n. 1, p. 139-158, 2009. 
ARTICLES - Technology transfer within mnes: inter-subsidiary competition and cooperation

HOSKISSON, R., HITT, M. Strategic control systems and relative R\&D investment in large multiproduct firms. Strategic Management Journal, 9(6): 605-621, 1988.

HYMER, . The international operations of national firms: A study of direct foreign investment. Cambridge, MA: MIT Press, 1976.

ISOBE, T., MAKINO, S., MONTGOMERY, D. Resource commitment, entry timing, and market performance of foreign direct investments in emerging economies: The case of Japanese international joint ventures in China. Academy of Management Journal, 43(3): 468-484, 2000.

JAYACHANDRAN, S., GIMENO, J., VARADARAJAN, P. The theory of multimarket competition: A synthesis and implications for marketing strategy. Journal of Marketing, 63: 49-66, 1999.

JOHANSON, J., VAHLNE, J. The internationalization process of the firm: A model of knowledge development and increasing foreign market commitments. Journal of International Business Studies, 8(1): 23-32, 1977.

KALNINS, A.. Divisional multimarket contact within and between multi-unit organizations. Academy of Management Journal, v. 47, part 1, p. 117 - 128, 2004.

KARNANI, A., WERNERFELT, B. Multiple point competition. Strategic Management Journal, 6: 87-96, 1985.

KOGUT, B. Jint Ventures and the Option to Expand and Acquire. Management Science, 37(1): 19-33, 1991.

KOGUT, B., ZANDER, U. Knowledge of the firm, combinative capabilities, and the replication of technology. Organization Science, 3: 383-397, 1992.

KOGUT, B., ZANDER, U. Knowledge of the firm and the evolutionary theory of the multinational corporation. Journal of International Business Studies, 24(4): 625-645, 1993.

KOSTOVA, T. Success of the transnational transfer of organizational practices within multinational enterprises. Unpublished doctoral dissertation, University of Minnesota, 1997.

LANE, P., SALK, J., LYLES, M. Absorptive capacity, learning, and performance in international joint ventures. Strategic Management Journal, 22(12): 1139-1161, 2001.

LAWRENCE, P., LORSCH, J. Organization and environment; managing differentiation and integration. Boston,: Division of Research Graduate School of Business Administration Harvard University, 1967.

LEAVITT, T. The globalization of markets. Harvard Business Review, May/June: 92-102, 1983.

LORD, M., RANFT, A. Organizational learning about new international markets: Exploring the internal transfer of local market knowledge. Journal of International Business Studies, 31: 573-589, 2000.

LORSCH, J., LAWRENCE, P. Organizing for product innovation. Harvard Business Review, Jan/Feb: 109120, 1965.

RAI - Revista de Administração e Inovação, São Paulo, v. 6, n. 1, p. 139-158, 2009. 
MARCH, J., SIMON, H. Organizations. New York: Wiley, 1958.

MASCARENHAS, B. The coordination of manufacturing interdependence in multinational companies. Journal of International Business Studies, 15(Winter): 91-106, 1984.

MJOEN, H., TALLMAN, S. Control and performance in international joint ventures. Organization Science, 8(3): 257-274, 1997.

NAVARETTI, G., TARR, D. International knowledge flows and economic performance: A review of the evidence. The World Bank Economic Review, 14(1): 1-15, 2000.

NELSON, R., WINTER, S. An evolutionary theory of economic change. Cambridge, Mass.: Belknap Press of Harvard University Press, 1982.

NOHRIA, N., GHOSHAL, S. The differentiated network: Organizing multinational corporations for value creation. San Francisco: Jossey-Bass Publishers, 1997.

PALMER, D., JENNINGS, P., ZHOU, X. Late adoption of the multidivisional form by large U.S. corporations: Institutional, political and economic accounts. Administrative Science Quarterly, 38(1): 100-131, 1993.

PENROSE, E. The theory of the growth of the firm. New York: Wiley, 1959.

Pfeffer, J., \& Salancik, G. The external control of organizations: A resource dependence perspective. New York: Harper \& Row, 1978.

PHENE, A., TALLMAN, S. Knowledge flows and geography in biotechnology. International Journal of Medical Marketing, 2(3): 241-254, 2002.

POLANYI, M. The tacit dimension. Garden City, NY, Doubleday, 1966.

PORTER, M. Changing patterns of international competition. California Management Review, 28(2): 9-40, 1986.

PORTER, M. Clusters and the new economics of competition. Harvard Business Review, 76(6): 77-90, 1998.

PRAHALAD, C. K. The strategic process in a multinational corporation. Harvard Business School, Boston, 1976.

PRAHALAD, C. K., DOZ, Y. The multinational mission: Balancing local demands and global vision. New York: Free Press, 1987.

SIMONIN, B. Transfer of marketing know-how in international strategic alliances: An empirical investigation of the role of antecedents of knowledge ambiguity. Journal of International Business Studies, 30: 1227-1247, 1999.

RAI - Revista de Administração e Inovação, São Paulo, v. 6, n. 1, p. 139-158, 2009. 
ARTICLES - Technology transfer within mnes: inter-subsidiary competition and cooperation

STRANG, D., SOULE, S. Diffusion in organizations and social movements: From hybrid corn to poison pills. Annual Review of Sociology, 24: 265-290, 1998.

SZULANSKI, G. Exploring internal stickiness: Impediments to the transfer of best practice within the firm. Strategic Management Journal, 17(Winter): 27-43, 1996.

TALLMAN, S., FLADMOE-LINDQUIST, K. Internationalization, globalization, and capability-based strategy. California Management Review, 45(1): 116-135, 2002.

TEECE, D. The multinational enterprise: Market failure and market power considerations. Sloan Management Review, 22(Spring): 3-17, 1981.

TEECE, D. Firm organization, industrial structure, and technological innovation, Journal of Economic Behavior \& Organization, 31(2): 193-224, 1996.

TEECE, D., PISANO, G., SHUEN, A. Dynamic capabilities and strategic management. Strategic Management Journal, 18(7): 509-533, 1997.

TRIPSAS, M. Unraveling the process of creative destruction: Complimentary assets and incumbent survival in the typesetter industry. Strategic Management Journal, 18 (Summer Special Issue): 119-142, 1997.

TUSHMAN, L. M., ANDERSON, P. Technological discontinuities and organizational environments. Administrative Science Quarterly, 31: 439-465, 1986.

WEJNERT, B. Integrating models of diffusion of innovations: A conceptual framework. Annual Review of Sociology, 28: 297-326, 2002.

WERNERFELT, B. A resource-based view of the firm. Strategic Management Journal, 5(2): 171-180, 1984.

WILLIAMSON, O. E. The economic institutions of capitalism: Firms, markets, relational contracting. New York: Free Press, 1985.

ZANDER, I., SOLVELL, O. Cross-border innovation in the multinational corporation: A research agenda. International Studies of Management \& Organization, 30(2): 44-67, 2000.

\section{TRANSFERÊNCIA DE TECNOLOGIA EM MNES: COMPETIÇÃO E COOPERAÇÃO INTER-SUBSIDIÁRIAS}

\section{Resumo}

Muitas das teorias e pesquisas procuram explicar por que e como a transferência de tecnologia acontece nas empresas multinacionais (MNE) dirigem-se a questão de como estas transferências ocorrem entre subsidiarias cooperativas, e assumem a cooperação inter-subsidiárias. Entretanto, nem sempre as subsidiárias cooperam. Sugerimos que o sucesso da transferência de tecnologia entre subsidiárias

RAI - Revista de Administração e Inovação, São Paulo, v. 6, n. 1, p. 139-158, 2009. 
depende da extensão da relação de cooperação ou competição entre as subsidiárias das MNE. A cooperação inter-subsidiária é determinada pela estratégia internacional da MNE, pela estrutura organizacional e pelas relações sociais entre as subsidiárias. Tanto os fatores de relações sociais como hierárquicos dirigem o potencial para a competição inter-subsidiária multi-mercado que se origina da sobreposição dos produtos, tecnologias e portfolios de mercado.

Palavras-chave: Transferência de tecnologia, subsidiárias, competição e cooperação, estratégia internacional.

Data do recebimento do artigo: 22/02/2009

Data do aceite de publicação: 20/03/2009

RAI - Revista de Administração e Inovação, São Paulo, v. 6, n. 1, p. 139-158, 2009. 